\title{
The Eradication of Women and Children Trafficking in Jember Regency in Relations to the Legal Protection for Victims in the Health Perspective
}

\author{
Yanny Tuharyati ${ }^{1}$, Muhammad Rusydianta ${ }^{2}$, Muhammad Rizal ${ }^{3}$, \\ Tri Siswanto ${ }^{4}$, Achmad Muchsin ${ }^{5}$, Zainur Wula ${ }^{6}$ \\ ${ }^{1}$ Doctoral of Law Student Universitas Islam Indonesia, Lecturer Universitas Muhammadiyah Jember, ${ }^{2}$ Doctoral \\ of Law Student Universitas Islam Indonesia, Lecturer Unida Gontor, ${ }^{3}$ Doctoral of Law Student Universitas Islam \\ Indonesia, ${ }^{4}$ Doctoral of Law Student Universitas Islam Indonesia, ${ }^{5}$ Doctoral of Law Student Universitas Islam \\ Indonesia, ${ }^{6}$ Associate Professor Universitas Muhammadiyah Kupang,
}

\begin{abstract}
The development of human trafficking has changed to happen to the kinds of people who are disadvantaged, such as woman and children. The trafficking of woman and children is one of the bad forms treatment from the exploitation activity which is faced by woman and children. Trafficking is included as a crime and a human rights violation. Indonesia itself is a region where woman and children trafficking happens, either as country of the victims' origin or as a transit country. Some regions in Indonesia are estimated as targets of border countries' crime syndicate activities which organize woman and children trafficking. This research analyzes the women and children trafficking in Jember Regency in the perspectives of law and health.
\end{abstract}

Keyword: Human Trafficking, Victim, Women, Children, Jember Regency, Health, Law.

\section{Introduction}

There is an interesting data which is released by the Center for Protection of Women and Children (Pusat Perlindungan Perempuan dan Anak/P3A) Jember. From a quick study conducted by ILO/IPEC on 2003 in East Java, it is shown that 4.081 people under 18 years old are estimated to become victims of children and woman trafficking. This study also stated Jember and eight other areas as places which are signaled to become the original areas of women and children trafficking victims who were to be sold for sex. The eight areas are Banyuwangi, Sampang, Malang, Blitar, Ponorogo, Pacitan, Gresik, and Nganjuk Regencies. Meanwhile, the areas in Jember Regency which are signaled to be the original areas of where the trafficking victims are sent from are Ambulu, Tempurejo, Puger, Arjasa, Patrang and Sumberbaru ${ }^{1}$.

\section{Corresponding Author:}

Yanny Turhayati

Jember Regency, Indonesia

e-mail: yanny@unmuhjember.ac.id
These days, there are more and more news on human trafficking in Indonesia, both in the domestic and transnational scales. There is only recent attention from the society through the mass media these last years towards the human trafficking of women and children in the sexual industry activity. Surely, it cannot be concluded that before this, the phenomenon did not happen. There is a chance of it happening in a small scale or in a wellorganized trafficking activity. This is part of the reason of why the trafficking news did not attract the attention of the mass media in the past ${ }^{2}$.

Indonesia becomes the state of origin, transit, and destination of human trafficking especially woman and children who are forced to become sexual workers or forced workers. The victims from Indonesia are brought to Malaysia, Singapore, Taiwan, Hongkong, Brunei, countries of the Persian Gulf, and Australia. The trafficking has also happened extensively in the Indonesian territory for sex and labor exploitation. Indonesia becomes one of the destination countries for the trafficking victims who are sold to be sexually exploited ${ }^{3}$. 
Based on the background above, it can be formulated that the research problem is: How is the eradication of the women and children trafficking in relations to the legal protection for the victims?

\section{Result and Discussion}

1. The Definition of Women and Children Protection: Based on the Constitution No. 21 of 2007 regarding the eradication of Human Trafficking, trafficking is the action of recruiting, transporting, sheltering, sending, moving, or bringing in someone with the threat of violence, the use of violence, kidnapping, captivating, fraud, deception, misuse of power to someone in a disadvantaged position, debt bondage, or giving payment or benefits so that there is the agreement from the person who has power over the stated person, both carried out within the country or between countries, with the aim of exploitation or to make someone become exploited.

The rampant case of human trafficking in Indonesia causes concerns to its people. There are various cases of human trafficking which happen nowadays based on the news of electronic or non-electronic media. Some of the research results which had been carried out show that the cases of human trafficking, especially those which happen to women and children, require serious attention.

The women and children trafficking which happen in Indonesia is usually with the aim of bringing them into prostitution. It also regards pornography, begging, or labor as household assistants. The women and children trafficking is a real violation of the basic human rights. It is complex as well as multidimensional and is carried out both blatantly and implicitly. These informations are obtained from the results of reports and data displays from various sources. As stated by Sumaryoto as the Minister of Women Empowerment ${ }^{4}$, to prevent the problem of women and children trafficking, the Indonesian government has carried out some efforts both which are practical and strategic.

\section{The Forms of Women and Children Trafficking:}

There are various forms of women and children trafficking. In reality, it is the same as the women and children trafficking which happen in European countries. Yet, to ease the identification, there are some forms or actions which may be categorized as the forms of women and children trafficking based on the research carried out by Syafaat. According to him, the forms of women and children trafficking which happen in Indonesia are as follows:

1. The adoption of children with the procedures or which are sold to citizens of Indonesia or to foreign citizens.

2. Involving children in the sales of drugs.

3. Pornography of women and children.

4. The trafficking of women and children to work by force.

5. Forcing women and children to work as beggars or to scrounge in the streets.

6. Forcing women and children to carry out sexual work or to become prostitutes ${ }^{5}$.

Then, according to a research carried out by Solidaritas Perempuan (The Solidarity of Women), the forms of women and children trafficking based on the cases found are not limited to forced prostitution or sex trade. Yet, they also include the forms stated by Syafaat.

\section{The Factors which Cause Women and Children} Trafficking to Happen in Jember: The main cause of the rampant trafficking cases towards the women and children in Jember Regency is poverty. People try to fix or to improve their economic condition by looking for work. But, obtaining work is not as easy as what they imagined. Some had to suffer in the process. As stated in the research carried out by Syafaat in East Java, the factors which cause women and children trafficking are as follows:

1. Difficult economic condition.

2. Disharmonious family.

3. Early-age marriage and divorce.

4. Early-age victim of sexual harassment.

5. Victim of rape.

6. Limited work opportunities.

7. Influence from other people who have successfully worked in various fileds. This happens as follows:

The victims of women and children trafficking are victims who experienced physical and psychological suffering. After the crime is over, they will still experience trauma and long suffering. From the cases of women and children trafficking found, most regard forced prostitution or sex trade. Apart from that, they also regard forms of work prostitution and practices like slavery in some areas in informal sectors including 
domestic work and wife-by-order ${ }^{6}$. The victims stated that before they are trafficked, they have already experienced terrible condition in the shelters. In those places, they are not equipped with skills. Instead, some have already been exploited to work without wage in living conditions which are not feasible, as stated by Fida, a companion of women and children trafficking victims in Jember Regency (personal communication, March 12, 2020).

Jember is divided into 28 districts. They holistically have a great potential for women and children trafficking, through the mediation of agents which come to villages. Usually, the agents as the recruiters directly enter the villages to find and to take women and children to be distributed to other agents as receptors. The victims will then become prostitutes. They may be trafficked to other areas or to other countries.

The modus operandi or the method of running the crime of women and children trafficking is usually through deception. This happens when the victims are influenced by the agents. They want to obtain a high wage, but then they are forced to become prostitutes. Most of the cases which happen in Jember Regency is prostitution.

From the cases of women and children trafficking which happen in Jember regency, the rights obtained by the victims are quite maximum. The victims are brought home if the case is uncovered. Also, if the victims ask for further investigation, this case may be filed to court. Yet, most victims do not want the case to be known extensively by the society as they regard the case as a disgrace. But, the gateway for the entrance of the criminal court process is the involvement of the victims in the criminal court, which is through reports and complaints.

Considering the complexity and the difficulty to detect the criminal act of human trafficking, thus there needs to be a regulation which is more suitable to the current condition. The regulations on human trafficking in the Indonesian constitution, as explained in the background, are not non-existant. Yet, they are deemed as inadequate.

Seeing the extensive definitions of human trafficking, there are no legal articles which can be used to cover all actions which are categorized as human trafficking in the limitations which currently apply according to the international society. If seen from the cases of women and children trafficking which happen in Jember Regency, there are some obstacles related to the legal protection for the victims, which are:

a. The Law or the Regulations: There are some articles which are specifically used to bind the perpetrators of women and children, which are Article 297 of the Criminal Code, Article 324 of the Criminal Code, and Article 329 of the Criminal Code. As explained in the previous part, there are some weaknesses of these articles. Then, the women and children trafficking are more specifically regulated in the Constitution No. 21 of 2007 regarding the Eradication of the Crime of Human Trafficking. With the Constitution No. 21 of 2007, the two articles in the Criminal Code which regulate the trafficking of women and children do not apply anymore. Yet, the existence of these regulations causes new problems for the law-enforcing apparatus, especially in the application of the articles.

The problem which may arise with the application of the new article in the constitution lies in the unclear words used in the formulation of some articles. As stated by Soekanto, this is because the definition of the words used may be interpreted extensively, or because the words used are translated from foreign languages ${ }^{7}$. Thus, one of the obstacles in the law enforcement which comes from the regulations is the unclear words used in the regulations which cause uncertainty in the interpretation and in the application.

b. The Law-Enforcing Apparatus: The lawenforcing apparatus highly require help from many parties, such as reports from the society as an information to uncover a case. Because of that, there are some factors which influence the uncovering of the trafficking case. The lack of the number of personnels, the lack of facilities and infrastructure, and the lack of funds become the police force's classical excuses in uncovering the cases of trafficking. These limitations are further added with the lack of the investigating personnel's abilities in uncovering the cases filed by the society. In the investigation process, the police force must have special abilities in handling the trafficking cases ${ }^{8}$.

Based on the results of a questionnaire given by the researcher to 50 police force personnels in the investigation and in the inquiry sections, 11 public proscecutors, 24 technical administrators in the Jember District Court which consists of the judges and the 
clerks, it can be concluded that the law-enforcing apparatus generally know about the existence of the women and children trafficking as they have not yet reached an understanding. This is proven by the results of the questionnaires given, considering that there must be special skills in handling the cases of trafficking.

c. The Trafficker: As mentioned before, the traffickers have an extensive network in this crime. Even though accurate evidences had not been found, yet it may be estimated that the perpetrator is a group of people within a certain organization, thus often called an organized crime. Such crimes involve many people and they have a rather extensive network. Thus, it is not impossible that the perpetrators of this crime is very difficult to be caught, even more so to bring them to the legal process.

Usually, their activities are difficult to be mapped out. It is also difficult to find who the real perpetrators are. Even, it is not impossible that they have known the police force's efforts in catching them. This results to them taking preventive actions, thus they may get away safely. The apparatus must be aware that the perpetrators who are caught are usually small-scale perpetrators or powerless "messengers". Meanwhile, the intellectual actors in the organized crime will never be caught. And there is an even less chance for them to be processed by the law'.

\section{d. The People's Perception on Human Trafficking:} The problem of human trafficking, especially that which happens to women and children is an example of the women's disadvantaged condition towards the sexual interests of men. The women's sexual image which places women as men's sexual object actually has a high impact towards women's lives. Thus, they must always face physical and mental violence, coercion, and torture. Because of that, the women and children trafficking is not only a reflection of the women's image as a sexual object, but it also reflects women as men's object of power. The weak position of women and children is actually a consequence of human's sexual differences. It is widely known that Indonesians are a patriarchal society which as a structure which derogates women. This happens both from the governmental policies and in the people's behavior.

4. The Protection for Women and Children Trafficking Victims from the Health Perspective: The traffricking victims generally face both physical and mental torture. Thus, they need special treatment. To achieve this, there needs to be a cooperation between the legal, psychological, and medical fields. This is so, because the victims experience torture in the shelters, which will influence their mental and physical health condition. The rights which must be obtained by the victims regarding the compensation for the loss they suffered are as follows ${ }^{10}$ :

1. Freedom from torture or harassment from the parties in control.

2. Adequate physical and psychological health services, which are confidential and affordable, which are provided by the state or private sectors which are funded by the government.

3. The protection of the victims' personal identities and information. Their names, addresses, and photos are prohibited from being published to the general public.

4. The victims have the right to obtain information regarding the results of the investigation. The victims and the families have the right to know if the traffickers are freed.

5. The victims have the right to be helped and to be assisted in the whole legal process.

All of these rights must be upheld for the enforcement of justice and welfare for the people. The rights obtained by the victims must also specially be handled by institutions which treat victims of women and children trafficking. As commonly known, the rights of the victims of these cases have not yet been maximally obtained by the victims. Most victims are only brought home. Worse, even if the case is handled by the lawenforcing apparatus, it is not completely uncovered.

\section{Conclussion}

Based on the explanation above, it can be concluded that the form of women and children trafficking which happen in Jember Regency is prostitution. The eradication of the women and children trafficking regards the protection towards the trafficking victims who experience both physical and mental sufferings. There needs to be a special treatment for the victims, thus, there needs to be a cooperation between the aspects of law, especially the three things which regard the law enforcement, like the constitution, the law-enforcing apparatus, and the society (culture). There also needs to be a cooperation with the fields of psychology and medicine. 


\section{Conflict of Interest: No}

Source of Funding: Author

Ethical Clearance: Yes

\section{References}

1. Hardani S. Importance of the state's role in the victims' recovery process. J. Perempuan. 2004;36.

2. Harkrisnowo Report of human trafficking in Indonesia. Jakarta: Sentra HAM UI; 2003. 4 p.

3. Iswarini SE. Survivor group: learning from the experiences of women who are trafficking victims. J. Perempuan. 2004;36.

4. Sumaryoto SR. To prevent women and children trafficking. In: Opening of Technical Education and Training on Gender Mainstreaming in the Education and Training Center of Central Java Province; 2002; Semarang.
5. Syafaat R. Dagang manusia: Human trafficking: analysis on women and children trafficking in East Java. Yogyakarta: Lappera Pustaka Utama; 2003.

6. Rahayan SS. Analysis of the law formulation on the eradication of the human trafficking crime. J. Perempuan. 2006;49.

7. Soekanto S. Factors which influence law enforcement. Jakarta: Raja Grafindo Persada; 2002.

8. Imelda JD. Debt, the ijon system in the female children trafficking in Yogyakarta. Yogyakarta: Universitas Gajah Mada Press; 2004. 8 p.

9. Nuh M. Jejaring anti traficking, The anti-trafficking network, the strategy in eradicating the women and children trafficking. Yogyakarta: Ford Foundation and Center of Policies and Demography, Universitas Gadjah Mada; 2005. 77 p.

10. Firdous. The responses of non-governmental organizations towards women trafficking [thesis]. Yogyakarta: Universitas Gadjah Mada; 2004.114 p. 